\title{
Et tua res agitur... - I ciebie rzecz dotyczy. Marcina Błażewicza studium ludzkiej wolności
}

\section{ET TUA RES AGITUR... - THIS CONCERNS TO YOU. THE STUDY OF FREEDOM BASED ON MARCIN BLAZEWICZ PERSCUSSION MUSIC}

Among many others contemporary composers, who uses percussion in their music, Marcin Blazewicz (professor of the Fryderyk Chopin Academy of Music in Warsaw) seems to be an extraoridinary. His compositions are inspired by the philosophy of Far East. They might be named as a persucussional works about being... Et tua res agitur is dedicated to the person of the priest Jerzy Popieluszko, who was murdered by communist regime. Is a musical story/tale about responsibility and suffering. The article shows not only the roots of the composition but also a practical approach od the performance and interpretation of Marcin Blazewicz composition.

Key words: percussion, Jerzy Popieluszko, responsibility, philosophy, far east, Marcin Blazewicz.

Jak to się dzieje, że w jednej kompozycji można pogodzić intuicyjne porywy emocji z wyszukanym intelektualizmem, subtelności duszy $\mathrm{z}$ burzą dźwiękową, tradycje sprzed tysięcy lat ze współczesnością, ład 
Theology of beauty formy z treściami o kosmicznym rozmachu? To właśnie jest tajemnicą talentu. Na szczęście nie wszystko w sztuce daje się wyjaśnić. ${ }^{1}$

Marcin Błażewicz należy do twórców, którym polska sztuka perkusyjna zawdzięcza znaczną część swojej tożsamości. Horyzonty twórcze kompozytora są odzwierciedleniem jego zainteresowań skupionych wokół gnostycyzmu, jogi, filozofii Dalekiego Wschodu a więc nurtów akcentujących olbrzymi potencjał drzemiący w człowieku, predestynujący go do autosoteriologii - samozbawienia, uzyskiwanego przez określone techniki medytacyjne. Zainteresowany tematem niniejszego artykułu czytelnik z pewnością może zadać pytanie, gdzie wśród tak zarysowanego kręgu inspiracyjnego znaleźć miejsce na chrześcijańskie wpływy, eksponujące motyw cierpienia człowieka i wynikającą z niego perspektywę Zbawienia? Odpowiedzi na nie może udzielić analiza choćby samych nazw dzieł kompozytora, który osobiście odżegnuje się od jakichkolwiek inspiracji chrześcijańskich/religijnych w swej twórczości:

Żyjemy w epoce wielkich przewartościowań. Wciąż przesuwają się najistotniejsze akcenty w naszym życiu wewnętrznym, w naszym życiu duchowym. Religia nie łączy nas już z sacrum, tę jej rolę przejęła sztuka, która prowadzi nas w głąb siebie, w otchłań spraw ostatecznych, ku jądru wieczności².

Spośród wielu tytułów ukazujących duchowe emergencje Błażewicza, wyjątkową i szczególnie interesującą w kontekście niniejszej wypowiedzi jest kompozycja Et tua res agitur, przeznaczona na perkusję solo, 2 trąbki i orkiestrę smyczkową. Wybitny polski historyk sztuki, filozof Krzysztof Lipka określił perkusyjne dzieła Marcina Błażewicza mianem ,traktatów filozoficznych"3 zwracając tym samym uwagę na ich metafizyczne podłoże oraz uniwersalny przekaz. Mimo, iż utwór o którym traktuje niniejszy referat w sposób znaczący odstaje ideowo od pozostałych, nasyconych Duchem Wschodu dzieł, jest w rzeczywistości obszerną muzyczno-filozoficzną wypowiedzią stanowiącą o wolności jednostki ludzkiej. Jego omówienie wydaje się szczególnie ważne w świetle zjawisk współczesności, w której prawa człowieka do bycia człowiekiem, do samostanowienia o sobie, do wolności są nieustannie łamane w wielu częściach świata. Celem niniejszej wypowiedzi nie jest

$1 \quad$ K. Lipka, M. Błażewicz, Filozoficzne traktaty perkusyjne Marcina Błażewicza, [w:] Zeszyty Naukowe nr 47, W kręgu sztuki perkusyjnej, red. S. Skoczyński, Warszawa 1999, s. 123.

2 Ibidem, s. 119.

3 Por. ibidem. 
zagłębianie się w zagadnienia polityczne, lecz w ten aspekt życia, który plasuje się ponad podziałami partyjnymi, ideologiami, religiami. Jest nim wolność i godność ludzka.

Et tua res agitur jest swego rodzaju manifestem muzycznym, napisanym na zamówienie Josepha Hertera ${ }^{4}$ - popularyzatora muzyki polskiej na terenie Stanów Zjednoczonych. Prawykonanie dzieła odbyło się w kościele św. Stanisława Kostki w Warszawie 21 października 1987 roku - w trzecią rocznicę tragicznej śmierci ks. Jerzego Popiełuszki, zamordowanego przez polskie władze komunistyczne. Należy zaznaczyć, iż dzieło nie jest manifestem politycznym czy religijnym. Inspiracje Błażewicza sięgają znacznie dalej - rzecz można do samego centrum zagadnienia, które wstrząsnęło Polakami w 1984 roku.

Analizowana kompozycja, poprzez głębię wyrazu jest muzycznym symbolem cierpienia i walki i jak każdy symbol może zostać odczytana na wiele sposobów. Symbol bowiem, według wybitnego historyka religii - Mircea Eliadego

odsłania pewne aspekty rzeczywistości - te najgłębsze - które wymykają się wszelkim innym sposobom poznania [...]. Obrazy, symbole, mity nie są przypadkowymi wytworami psychiki, odpowiadają pewnej określonej potrzebie i spełniają określoną funkcję, polegającą na obnażeniu najskrytszych form istnienia [...]. Obrazy i symbole [...] umożliwiają nam wielokrotne powracanie do rajskiego stadium praczłowieka ${ }^{5}$.

Marcin Błażewicz nie narzuca odbiorcy utworu konkretnego jego rozumienia czy interpretacji. Poprzez podtytuł funeral music daje jedynie do zrozumienia, iż dotyka ona treści ważkich, ostatecznych, wymykających się kartezjańskiemu widzeniu świata.

Genialna muzyka tworząca kompozycję przeznaczoną na perkusję solo, 2 trąbki i orkiestrę smyczkową, po raz kolejny staje się nośnikiem treści filozoficznych. Celowo użyłem w tym miejscu sformułowania „po raz kolejny”, jako że omawiany utwór, mimo swej inspiracyjnej odrębności doskonale wpisuje się w nurt głębokich, metafizycznych dzieł Błażewicza - zarówno tych komponowanych latach 80. i 90. (Arista - death omen, Credo, Ineffabilis) jak i tych powstałych w XXI wieku (Kali-Yuga).

Tym razem kompozytor zadaje pytanie, kiedy możemy mówić o wolności człowieka i jaki jest związek wolności z odpowiedzialnością. Tragiczna śmierć księdza jest utożsamiana przez twórcę ze śmiercią każdego człowieka, którego najbardziej naturalnym prawem jest prawo do wolności. Struktura państwa totalitarnego ową wolność zabija, nie

4 Por. http://www.cantoresminores.pl/?employees=joseph-a-herter.

$5 \quad$ M. Eliade, Obrazy i symbole, Warszawa, 1998. 
toleruje indywidualności i wolnego myślenia, traktując jednostki ludzkie nie jako osobne, niezależne „byty” lecz jako masę, tłum. Można więc powiedzieć, że Et tua res agitur jest dziełem napisanym ku przestrodze, by patologiczna sytuacja, w której państwo decyduje o życiu i śmierci obywateli już nigdy się nie powtórzyła. Błażewicz opisując muzycznie przypadek chrześcijańskiego bojownika o wolność dotyka istotnego zagadnienia sytuacji granicznych, opisanych przez Karla Jaspersa:

Theology of beauty

Sytuacjami granicznymi nazywam to, że stale znajduje się w jakichś sytuacjach, że nie mogę żyć bez walki i cierpienia, że biorę na siebie winę i nie mogę tego uniknąć, wreszcie, że muszę umrzeć. (...) Są jak mur, o który uderzamy, o który się rozbijamy. Nie potrafimy ich zmienić, lecz jedynie naświetlić, nie mogąc ich wywieść i wyjaśnić przez odniesienie do czego innego ${ }^{6}$.

Marcin Błażewicz zwraca w swym dziele szczególną uwagę na zagadnienie przezwyciężenia samego siebie, które bliskie jest wielu nurtom filozoficznym i religijnym. Pokonywanie własnych ograniczeń, strachu warunkuje bowiem progres duchowy. Ten z kolei generuje piękno istoty ludzkiej: „Postawiłem cię pośrodku świata, abyś tym łatwiej mógł spoglądać dookoła siebie i widzieć to, co jest. Stworzyłem Cię jako istotę ani niebiańską, ani ziemską [...], abyś mógł samego siebie rzeźbić i przezwyciężać"7.

W jaki sposób powinien zachować się człowiek w obliczu utraty wolności i zbliżającej się śmierci? Kompozytor uzależnia odpowiedź od tego „czy jest w nas Wiara, Nadzieja, czy Zwątpienie i Nicość”. Należy zwrócić uwagę, iż wymienione cztery stany emocjonalne, w niewątpliwy sposób wpływające na postrzeganie eschatologicznego aspektu życia, Błażewicz w sposób całkowity stara się uniezależnić od religii, pozostając tym samym w zgodzie z własnym światopoglądem. Niezależnie jednak od tego, czy utwór interpretujemy w duchu wiary, czy też w duchu świeckim, w centrum błażewiczowskich rozważań stoi człowiek - istota „rozpostarta” między wiecznym duchem i przemijającą materią... Wiara w osobowego Boga, lub we własne możliwości, implikująca hipotetyczną zmianę zastanej rzeczywistości daje nadzieję, mającą związek z empatią i kwestią odpowiedzialności za losy drugiego człowieka. To właśnie ona sprawia, że w sytuacjach całkowitego rozbicia wewnętrznego jesteśmy w stanie się podnieść i dokonać wielkich czynów. Zwątpienie i nicość, mogą być natomiast postrzegane jako rodzaj acedii, zwątpienia, gnuśności, któremu poddanie się może być przyczyną zła wyrządzonego drugiemu człowiekowi...

$6 \quad$ R. Rudziński, Jaspers, Warszawa 1978, s. 188.

7 G. Picó della Mirandóla, Mowa o godności człowieka, Warszawa 2010. 
Et tua res agitur Marcina Błażewicza, wpisuje się w nurt muzyki żałobnej. Stanowi muzyczne rozwinięcie myśli kompozytora, mówiącej o tym, iż ,jesteśmy byciem w stronę śmierci i z tej perspektywy możemy dopiero żyć właściwie, nadając każdej chwili sens jedyny, bo niepowtarzalny". Kompozycja będąca rodzajem traktatu o ludzkich drogach, o dokonywaniu wyborów, składa się z kilku fragmentów o zróżnicowanej energetyce:

- fragment muzyczny zanotowany od początku dzieła do oznaczenia wykonawczego misterioso e solare;

- fragment muzyczny od oznaczenia wykonawczego misterioso $e$ solare, do perkusyjnej kadencji;

- perkusyjna kadencja;

- fragment muzyczny tutta la forza, lamentabile con dolore e ben sonore, łącznie ze zmianą tempa w literze $\mathrm{K}$;

- epilog/coda - fragment muzyczny od litery $\mathrm{N}$ do końca kompozycji.

Poniżej przedstawiono schemat instalacji perkusyjnej wraz z opisem, powstały w oparciu o praktykę wykonawczą autora artykułu.

Ryc. 1. Marcin Błażewicz, Et tua res agitur. Schemat instalacji multiperkusyjnej: ksylofon ${ }^{9}, 2$ kotły $(6,7)$, gran cassa profondo (1), 3 tom-tomy $(3,4,5)$, tom-tom kontrabasowy $(2), 2$ werble $(11,12)$, tam-tam profondo (9), 2 gongi jawajskie (8), 2 tybetańskie/japońskie misy świątynne spoczywające na trapie (10), wykonawca (13).

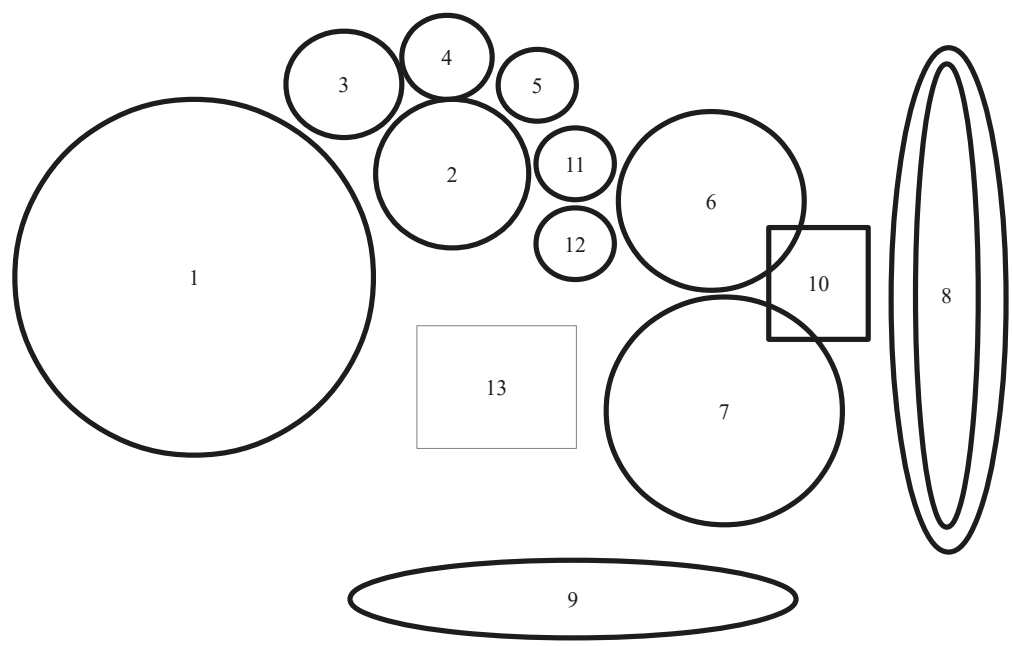

$8 \quad$ M. Błażewicz, książeczka dołączona do płyty Marcin Błażewicz, KOS Records, CD 06, 1993

$9 \quad$ Ksylofon znajduje się w orkiestrze, a jego partia nie jest wykonywana przez solistę. 
Wewnętrzne części utworu charakteryzujące się różnymi energetykami tworzą wartką narrację, rodzaj opowieści, w której uczucie bólu i niepokoju przeplata się z momentami emocjonalnego suspensu. Owe momenty „zawieszenia energetycznego” nie przynoszą jednak ukojenia; dają jedynie namiastkę chwilowego wytchnienia w walce - zarówno tej wewnętrznej, osobistej, duchowej jak i zewnętrznej, związanej z realiami ostatnich dwóch dekad minionego wieku.

Pierwszy z wyróżnionych przeze mnie fragmentów muzycznych zbudowany jest z potężnych pionów dźwiękowych wykonywanych tutti przez orkiestrę smyczkową. Ich konstrukcja horyzontalna opiera się na interwałach sekundowych, przydając im tym samym klasterowego charakteru. Tworzone przez Błażewicza płaszczyzny klastero-

Theology of beauty we przemieszczają się w kierunku opadającym lub wznoszącym się. Rozedrgana wewnętrznie tkanka muzyczna wsparta jest brzmieniem najniższego kotła (dźwięk E); dyspozycja rytmiczna perkusji zasadza się na podziałach sekstolowych. Muzyka początkowych taktów dzieła utrzymana jest w wysokich wartościach dynamicznych. Jej energetyka jest dodatkowo potęgowana przez liczne wycofania dynamiczne oraz crescenda, realizowane na krótkim odcinku czasu. Zastosowanie małych rozpiętości interwałowych (zarówno w płaszczyźnie horyzontalnej jak i wertykalnej) sprawia, iż odbiorcy działa mają uczucie falowania, wewnętrznego rozwarstwienia dźwięku. Pojawiające się w partii pierwszych skrzypiec liczne mikro glissanda przydają omawianemu fragmentowi dzieła lamentacyjnego charakteru.

Dalsza część utworu zbudowana jest z drobnych struktur trzydziestodwójkowych, sprawiających wrażenie niejednolitej wewnętrznie „dźwiękowej magmy”. Każda z grup instrumentalnych posiada w jej obrębie mini solo, składające się ze wspomnianych interwencji trzydziestodwójkowych, kwintolowych, triolowych, których energetyka wsparta jest licznymi crescendami i nagłymi wycofaniami dynamicznymi. Należy zaznaczyć, iż istotną rolę w sonorystyce tego fragmentu działa odgrywają flażolety, w znakomity sposób odrealniające naturalne, pełne brzmienie dźwięku. Projekcja dźwiękowa smyczków realizowana jest bez efektu vibrato, czego efektem jest uzyskanie „zimnego”, przenikliwego, zdawać by się mogło zawieszonego w dźwiękowej próżni brzmienia (określenie freddo, non vibrato). Dodatkowym zabiegiem sonorystycznym jest wprowadzenie dźwięków dobachi - tybetańskich mis świątynnych umieszczonych na membranie kotła ${ }^{10}$.

$10 \quad$ W opisanym przypadku kocioł traktowany jest w funkcji instrumentu/narzędzia rezonującego. Drgania misy tybetańskiej są przekazywane membranie instrumentu, która poprzez zmianę naprężenia wzmacnia i moduluje ich dźwięk. 
Perkusyjna kadencja, stanowiąca najbardziej wirtuozowski fragment kompozycji, oparta jest na podstawowym, sekstolowym materiale rytmicznym, zarysowanym na początku dzieła. Jej cechą charakterystyczną jest nieustanny progres dynamiczny, agogiczny i fakturalny, przebiegający od struktur homofonicznych do skomplikowanej polifonii. Początkowe, pojawiające się w niskich wartościach dynamicznych interwencje dźwiękowe gran cassy i tom-tomu kontrabasowego, przedzielane są fermatami o zróżnicowanym czasie trwania. Czas ów przeznaczony jest na całkowite wybrzmienie instrumentów. Błażewicz zwraca tym samym uwagę na ważkość ciszy w muzyce; ciszy, która mówi często więcej niż same dźwięki. Umożliwia bowiem kontemplację, rodzaj zapadnięcia się w siebie, wewnętrzną, duchową syntezę.

Wraz z sukcesywnym przyspieszaniem fermaty przedzielające poszczególne sekstolowe struktury ulegają skracaniu; wprowadzone zostają również dźwięki pozostałych membranofonów. Ewolucja materiału muzycznego zmierza w kierunku maksymalnego zagęszczenia faktury.

Ryc. 2. Marcin Błażewicz, Et tua res agitur, perkusyjna kadencja. Fragment partytury

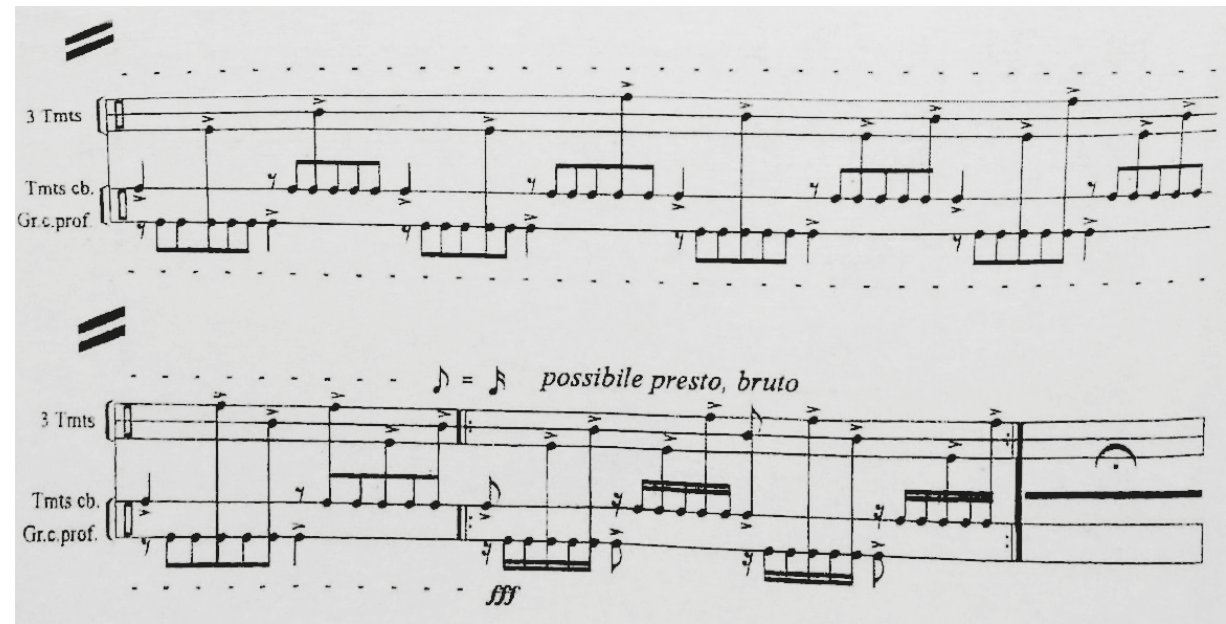

Po osiągnięciu największego nasycenia energetycznego w solowej partii perkusji, kompozytor wprowadza brzmienia trąbek, generowane zdawać by się mogło „bez oddechu”. Kumulowana energia nie zostaje rozładowana od razu. Jej ostateczną erupcję poprzedza pauza generalna, będąca rodzajem wstrzymania oddechu przed ostatecznym 
„unicestwieniem”. Jest to rodzaj zapowiedzi muzycznej ekspiacji, oczyszczenia, pokuty przywracającej jedność z Bogiem.

Od określenia subito tempo następuje nagła zmiana rytmiki. Kompozytor tworzy dwie, heterogeniczne płaszczyzny muzyczne:

- punktualistyczną, realizowaną przez rytmiczne unisona perkusji i orkiestry smyczkowej, definiowaną przez podziały ćwierćnutowo-ósemkowe;

- stałą, osiągniętą przez rytmiczną statykę dźwięków trąbek.

Trzy, przedzielone pauzami generalnymi interwencje smyczkowego, perkusyjnego i trąbkowego tutti (acuto) zrywają snutą do tej pory muzyczną tkankę dzieła. Należy w tym miejscu wspomnieć o symbolice cyfry 3 , która dla kompozytora jest niezwykle istotna. Błażewicz upa-

Theology of beauty truje w niej nie tylko religijnych konotacji, objawiających się w trójpostaciowości Boga ${ }^{11}$, ale przede wszystkim symbolu doskonałości we wszystkich aspektach życia, w tym również w sztuce.

Ostatni, dziewięciotaktowy fragment utworu określony przeze mnie jako coda, zbudowany jest z długo wybrzmiewających, flażoletowych reminiscencji tematu głównego, utrzymanego tym razem w niskich wartościach dynamicznych - w charakterze freddo, non vibrato, misterioso. Energetyczna statyka będąca następstwem wspomnianej dyspozycji materiału dźwiękowego zamyka dzieło, skłaniając do głębokiej refleksji nad ludzkimi drogami.

Kompozytor nawiązując w muzyczny sposób do wydarzeń, jakie rozegrały się w Polsce w latach 80 ., pragnie zatrzymać ową tragiczną chwilę, by w czasach współczesnych mogła ona wybrzmieć pełnią swej głębi, by nie odeszła w zapomnienie. W kontekście „trwania chwili” w innym, lecz również stanowiącym o śmierci utworze Marcina Błażewicza, cytowany już Krzysztof Lipka napisał:

[...] podobne założenie, uczynione w odniesieniu do dzieła opisującego śmierć kogoś z najbliższych, nabiera szczególnego sensu: oto bowiem mijający czas, który stępia w nas poczucie bólu, nie jest w stanie naruszyć tej części przeżyć, które zastały zawarte w utworze. ${ }^{12}$

Można więc pokusić się o tezę, iż muzyczne traktaty filozoficzne Marcina Błażewicza stanowią rodzaj duchowej kroniki dokumentującej istotne wydarzenia rozgrywające się zarówno w świecie materialnym jak i duchowym. Analiza i złamanie sekretnych kodów kompozycji pozwalają na uświadomienie sobie, kim jesteśmy i dokąd tak naprawdę

\footnotetext{
11 W chrześcijaństwie - Bóg Ojciec, Syn Boży, Duch Święty, w hinduizmie - Brahma, Wisznu, Sziwa...

$12 \quad$ K. Lipka, M. Błażewicz, Filozoficzne traktaty perkusyjne, s. 114.
} 
zmierzamy, definiując tym samym widzenie życia i śmierci w odpowiedniej, wzajemnie uzupełniającej się perspektywie.

Et tua res agitur powstał z namysłu nad miejscem człowieka we współczesnym świecie, nad śmiercią, nad problemem wolnej woli i odpowiedzialności, nad ostatecznym argumentem, którym może stać się śmierć [...]. Dla każdego z nas jest ona czymś innym, w zależności od tego, czy jest w nas Wiara, Nadzieja, Zwątpienie czy Nicość. ${ }^{13}$

\section{ET TUA RES AGITUR... - I CIEBIE RZECZ DOTYCZY. MARCINA BŁAŻEWICZA STUDIUM LUDZKIEJ WOLNOŚCI}

Spośród wielu współczesnych kompozytorów przeznaczających swe dzieła na perkusję postać Marcina Błażewicza - twórcy związanego z Uniwersytetem Muzycznym Fryderyka Chopina w Warszawie, jawi się jako szczególna. Jego kompozycje inspirowane często (choć nie tylko) filozofią Dalekiego Wschodu można określić mianem filozoficznych traktatów perkusyjnych, podnoszących tematy bytu, przemijania. W tak zarysowanym kręgu inspiracyjnym i ideologicznym analizowany w niniejszym referacie utwór zajmuje istotne miejsce. Et tua res agitur dedykowane pamięci zamordowanego ks. Jerzego Popiełuszki jest muzyczną opowieścią o ludzkich drogach, pokonywaniu samego siebie, odpowiedzialności i cierpieniu. W artykule odnajdziemy nie tylko wiele informacji na temat genezy dzieła, ale również uwagi wykonawcze i interpretacyjne wyrosłe na gruncie praktyki estradowej autora.

Słowa kluczowe: perkusja, Jerzy Popiełuszko, odpowiedzialność, filozofia, Daleki Wschód, Marcin Błażewicz.

\section{Bibliografia:}

1. Antokoletz E., Muzyka XX wieku, Inowrocław 2009.

2. Błażewicz M., książeczka dołączona do płyty The Darkes Dark - Mystery of Self Liberation, Warszawa 1999.

3. Błażewicz M., książeczka dołączona do płyty Marcin Błażewicz, KOS Records, CD 06, 1993.

4. Dąbek S., Twórczość mszalna kompozytorów polskich XX wieku, Warszawa 1996.

5. Eliade M., Historia wierzeń i idei religijnych; t. I; tł. S. Tokarski, A. Kuryś, Warszawa 1994-1997.

6. Hart M., Lieberman F., Planet drum, San Francisco 1991.

7. Hart M., Stevens J., Drumming at the edge of magic, New York 1990

13 M. Błażewicz, książeczka dołączona do płyty Marcin Błażewicz, KOS Records, CD 06, 1993. 
8. Jung C.G, Archetypy i symbole, Warszawa 1993.

9. Kotoński W., Leksykon wspótczesnej perkusji, Warszawa 1999.

10. Lorent L., Ineffabilis. Perkusyjne dzieła Marcina Błażewicza, Warszawa 2015.

11. Lorent L., Szkice perkusyjne, Warszawa 2014.

12. Maffit R., Rhythm \& Beauty, the art of percussion, New York 1999.

13. Mirandola G., Mowa o godności cztowieka, tł. Z. Nerczuk, M. Olszewski, Warszawa 2010.

14. Skoczyński S. red., W kręgu sztuki perkusyjnej, Zeszyty Naukowe AMFC nr 47, Warszawa 1999. 